\title{
Prevalence and Antibiotic Sensitivity of Motile Aeromonas in Dogs
}

\author{
E. CEYLAN ${ }^{\mathrm{A}}$, M. BERKTAS ${ }^{\mathrm{B}}$, H. KORKOCA ${ }^{\mathrm{B}}$, I. KELES ${ }^{\mathrm{A}}$, H. BOZKURT ${ }^{\mathrm{B}}$, M. G. KURTOGLU

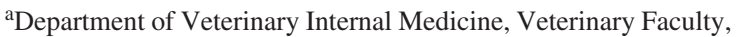 \\ Yuzuncu Yil University, Van, Turkey \\ bDepartment of Microbiology and Clinical Microbiology, Medical Faculty \\ and Research Hospital, Yuzuncu Yil University, Van, Turkey
}

Received July 19, 2002

Accepted November 29, 2003

\begin{abstract}
Ceylan E., M. Berktas, H. Korkoca, I. Keles, H. Bozkurt, M. G. Kurtoglu: Prevalence and Antibiotic Sensitivity of Motile Aeromonas in Dogs. Acta Vet. Brno 72, 2003: 607-612.

The present study was carried out to assess the prevalence of motile Aeromonas sp. in the faeces of healthy dogs and to evaluate its susceptibility to some anti-microbial agents. Rectal swabs from 55 domestic dogs were examined for Aeromonas species using alkaline peptone water ( $\mathrm{pH} 8.4$ ) as the enrichment medium and Aeromonas Selective Agar containing $5 \mathrm{mg} / \mathrm{l}$ ampicillin as the plating medium. Identification and antibiotic resistance of motile Aeromonas strains was performed using Gram Negative Breakpoint ID panel. After examining these samples, aeromonads were isolated from three $(5.45 \%)$ dogs. Of those, one was A. sobria, and two were A. caviae. While all isolated strains were sensitive to amikacin, cefoperazone, cefotaxime, cefotetan, ceftazidime, ceftriaxone, cefuroxime, ciprofloxacin, gentamicin, imipenem, piperacillin, tetracycline, ticarcillin, ticarcillin/clavulanate, tobramycin, and trimethoprim/sulfamethoxazole, they were resistant to ampicillin, and ampicillin/sulbactam. In addition, a strain of $A$. caviae was also resistant to aztreonam.

As a result, in the present study, information about the prevalence of Aeromonas in dogs, susceptibility to antibiotics of these microorganisms and its importance for both animal and public health were discussed.

Aeromonas, dog, prevalence, antibiotic sensitivity
\end{abstract}

Aeromonas spp. are gram-negative rods commonly found in freshwater sewage and soil (Quinn et al. 1994). Species of the genus Aeromonas have long been recognized as pathogens of amphibians and reptiles (Shotts et al. 1972), fish and snail (Popoff 1984). Known risk factors for disease in humans include drinking or swimming in contaminated water and also ingestion of contaminated food. Direct contact with contaminated animals and using ineffective antimicrobial agents are the other risk factors. Foods of animal origin and contaminated animals may play an important role in the transmission of the aeromonads from food or animals to humans, and animal faeces appear to be the major source of contamination of foods (Moyer 1987; Jindal et al. 1993). The isolation of motile aeromonads from dog faeces has been reported in a few studies. Aeromonas species in the faeces of domestic dogs may pose a public health problem for humans who come into contact with such animals (Akan et al. 1996; Ghenghesh et al. 1999). Therefore, the present study was carried out to assess the prevalence of motile Aeromonas sp. in the faeces of healthy dogs and to evaluate its susceptibility to some antimicrobial agents.

\section{Materials and Methods}

Dog Faecal Specimens

Faecal specimens were obtained from 55 healthy dogs randomly for the isolation of motile aeromonads using sterile swabs. The specimens collected were immediately transported to the laboratory in Alkaline peptone water (APW).

Address for correspondence:

Dr. Ebubekir CEYLAN

Posta Kutusu 139

TURKEY
Phone: $+0532-2051600$

Fax: +0432-215 5281

http://www.vfu.cz/acta-vet/actavet.htm 
Isolation Media

APW (pH:8.4) was used for enrichment medium, and Aeromonas Selective Agar (Oxoid, CM833) containing 5 $\mathrm{mg} \cdot \mathrm{l}^{-1}$ ampicillin was used as selective differential plating medium for Aeromonas spp. (Ampicillin Selective Supplement, SR136).

Oxidase test

This test was performed using oxidase identification sticks (Oxidase BR 64, Oxoid).

Catalase test

A small amount of a suspected colony was placed on a microscope slide and a drop of catalase reagent (hydrogen peroxide, $3 \%$ ) was added. When the colony was catalase-positive, gas bubbles were produced and test was evaluated as positive.

Oxidation - Fermentation (O-F) Test

$\mathrm{O} / \mathrm{F}$ test was performed with oxidation-fermentation basal medium (Difco, D0688-02). Before use, 2 tubes of $\mathrm{O} / \mathrm{F}$ medium, with loosened caps, were heated in a beaker of boiling water to drive off dissolved oxygen. After steaming for a few minutes, the tubes were cooled rapidly under cold running water. Both tubes of media were stab inoculated with the test organism, using a straight wire. Immediately added a layer of sterile paraffin oil to a depth of about $1 \mathrm{~cm}$ on the top of one of the tubes. Then, incubated at $37^{\circ} \mathrm{C}$ for up to 14 days. The results were evaluated by the colour change on the tubes. Development of a yellow colour in tubes with and without oil was considered as positive reaction.

Sceptor Gram-Negative Breakpoint ID Panel

Identification of motile Aeromonas strains was based on following biochemical reactions in Gram-Negative Breakpoint ID Panel (Sceptor Panel Code: 280 430, Becton Dickinson, USA): Citrate, Polymixin B, Dextrose, Malonate, Esculin, PNPG, Lysin, Arginine, Ornithine, Urea, $\mathrm{H}_{2} \mathrm{~S}$, Indol, Rhamnose, Melibiose, Mannitol, Arabinose, Xylose, Sucrose, Dnase, NPC, Glycin. These biochemical tests were confirmed by conventional biochemical tests.

The VP (Voges-Proskauer) test

Strains were inoculated into the Clark-Lubs medium and incubated for $24 \mathrm{~h}$ at $37^{\circ} \mathrm{C}$. One $\mathrm{ml}$ of medium taken from this inoculate was transferred to a sterile tube. Then $0.6 \mathrm{ml}$ alpha naphtol, thereafter $0.2 \mathrm{ml} \mathrm{KOH}$ added to the tube and then mixed well before waiting for 10-15 min. The test result was assessed as positive when red colour developed.

Isolation and Identification

Faecal specimens obtained with sterile swabs were inoculated into $10 \mathrm{ml}$ of alkaline peptone water (APW, $\mathrm{pH}$ 8.4) for the purpose of enrichment, and incubated for $24 \mathrm{~h}$ at $28^{\circ} \mathrm{C}$. Then, incubated material was inoculated into Aeromonas Selective Agar and incubated for $24 \mathrm{~h}$ at $37^{\circ} \mathrm{C}$.

Growing bacteria colonies in the medium were examined for oxidase and catalase positive, fermentative, motile, Gram-negative rods. Positive samples for these tests were identified as Aeromonas spp. using the Sceptor GramNegative Breakpoint ID Panel (Beckton-Dickinson, USA) and biochemical tests. The Voges-Proskauer (VP) test was performed to the strains identified as A. hydrophila/caviae in the Sceptor Gram Negative Breakpoint ID Panel. VP negative strains were identified as A. caviae.

Sensitivity to antimicrobial agents

Sensitivity tests on the identified Aeromonas spp. were performed with the Sceptor Gram Negative Breakpoint ID Panel (Panel code:280 430, Becton Dickinson-USA). With this panel, their sensitivity to amikacin, amoxicillinclavulanate, ampicillin, ampicillin-sulbactam, aztreonam, cefazolin, cefoperazone, cefotaxime, cefotetan, ceftazidime, ceftriaxone, cefuroxime, ciprofloxacin, gentamicin, imipenem, piperacillin, tetracycline, ticarcillin, ticarcillin-clavulanate, tobramycin, and trimethoprim-sulfamethoxazole were examined. The results were confirmed using by Kirby-Bauer disc diffusion method in agreement with recommendation of the NCCLS.

\section{Results}

Three motile Aeromonas spp. (5.45\%) were isolated from 55 faecal samples obtained from dogs. One of the isolated strain from the Sceptor Gram Negative Breakpoint ID panel was Aeromonas sobria and two of them were A. hydrophila/caviae. Voges-Proskauer test was performed to identify A. hydrophila and A. caviae. Because of the results of VP test of these two strains were negative, these strains were identified as Aeromonas cavia. The failure to grow of enterotoxigenic A. trota on selective media may be attributed to the ampicillin 
susceptibility of this strain. Antimicrobial sensitivity results of the strains isolated from the Sceptor Gram Negative Breakpoint ID panel were confirmed using disc diffusion method. Three strains of motile aeromonads isolated were examined for sensitivity to different antimicrobial agents. The agents applied for sensitivity test and MIC values obtained are given in Tables 1 and 2 .

Table1

The results of antimicrobial agents sensitivity test.

\begin{tabular}{|c|c|c|c|c|c|c|c|c|c|c|c|c|c|c|c|c|c|c|c|c|c|}
\hline Organisms & 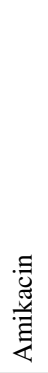 & 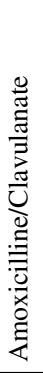 & 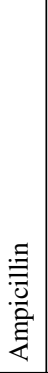 & 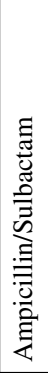 & 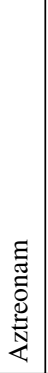 & 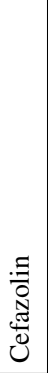 & 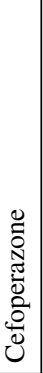 & 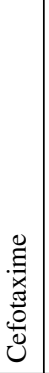 & 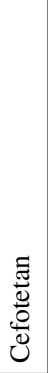 & 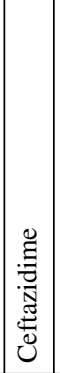 & 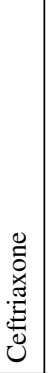 & 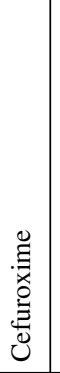 & 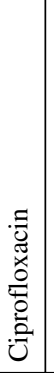 & 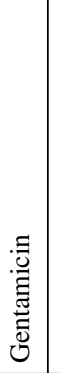 & 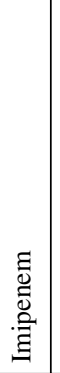 & 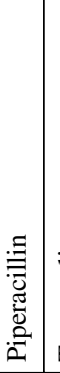 & 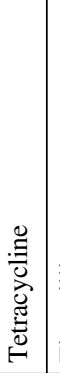 & 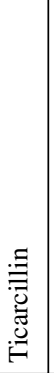 & 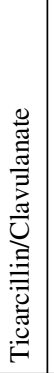 & 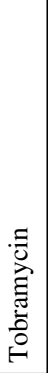 & 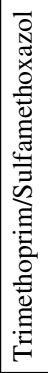 \\
\hline A. sobria & $\mathrm{S}$ & $\mathrm{S}$ & $\mathrm{R}$ & $\mathrm{R}$ & $\mathrm{S}$ & $\mathrm{S}$ & $\mathrm{S}$ & $\mathrm{S}$ & $\mathrm{S}$ & $\mathrm{S}$ & $\mathrm{S}$ & $\mathrm{S}$ & $\mathrm{S}$ & $S$ & $\mathrm{~S}$ & $\mathrm{~S}$ & $\mathrm{~S}$ & $\mathrm{~S}$ & $S$ & $\mathrm{~S}$ & $S$ \\
\hline A.caviae-I & $\mathrm{S}$ & $\mathrm{S}$ & $\mathrm{R}$ & $\mathrm{R}$ & $\mathrm{R}$ & $\mathrm{S}$ & $\mathrm{S}$ & $\mathrm{S}$ & $\mathrm{S}$ & $\mathrm{S}$ & $\mathrm{S}$ & $\mathrm{S}$ & $\mathrm{S}$ & $\mathrm{S}$ & $\mathrm{S}$ & $\mathrm{S}$ & $\mathrm{S}$ & $\mathrm{S}$ & $\mathrm{S}$ & $\mathrm{S}$ & $\mathrm{S}$ \\
\hline A. caviae-II & $\mathrm{S}$ & $\mathrm{I}$ & $\mathrm{R}$ & $\mathrm{R}$ & $\mathrm{S}$ & $\mathrm{I}$ & $\mathrm{S}$ & $S$ & $\mathrm{~S}$ & S & $\mathrm{S}$ & $\mathrm{S}$ & $\mathrm{S}$ & $\mathrm{S}$ & $\mathrm{S}$ & $\mathrm{S}$ & $\mathrm{S}$ & $\mathrm{S}$ & $S$ & $\mathrm{~S}$ & $S$ \\
\hline
\end{tabular}

$\mathrm{R}=$ Resistant; $\mathrm{S}=$ Sensitive; $\mathrm{I}=$ Intermediate

Table 2

MIC values of antimicrobial agents

\begin{tabular}{|l|c|c|c|}
\hline \multirow{2}{*}{ Antimicrobial Agents } & \multicolumn{2}{|c|}{ MIC Values (Mcg/ml) } \\
\cline { 2 - 4 } & A. sobria & A. caviae-I & A. caviae-II \\
\hline Amikacin & $<=16$ & $<=16$ & $<=16$ \\
Amoxicillin-clavulanate & $<=8$ & $<=8$ & 16 \\
Ampicillin & $>=32$ & $>=32$ & $>=32$ \\
Ampicillin-sulbactam & $>=32$ & $>=32$ & $>=32$ \\
Aztroenam & $<=8$ & $>=32$ & $<=8$ \\
Cefazolin & $<=8$ & $<=8$ & 16 \\
Cefoperazone & $<=16$ & $<=16$ & $<=16$ \\
Cefotaxime & $<=8$ & $<=8$ & $<=8$ \\
Cefotetan & $<=16$ & $<=16$ & $<=16$ \\
Ceftazidime & $<=8$ & $<=8$ & $<=8$ \\
Ceftriaxone & $<=8$ & $<=8$ & $<=8$ \\
Cefuroxime & $<=4$ & $<=4$ & $<=4$ \\
Ciprofloxacin & $<=1$ & $<=1$ & $<=1$ \\
Gentamicin & $<=4$ & $<=4$ & $<=4$ \\
Imipenem & $<=4$ & $<=4$ & $<=4$ \\
Piperacillin & $<=16$ & $<=16$ & $<=16$ \\
Tetracycline & $<=4$ & $<=4$ & $<=4$ \\
Ticarcillin & $<=16$ & $<=16$ & $<=16$ \\
Ticarcillin-clavulanic acid & $<=16$ & $<=16$ & $<=16$ \\
Tobramycin & $<=4$ & $<=2$ & $<=4$ \\
Trimethoprim-sulfamethexazole & $<=2$ & $<2$ \\
\hline
\end{tabular}


While all isolated strains were sensitive to amikacin, cefoperazone, cefotaxime, cefotetan, ceftazidime, ceftriaxone, cefuroxime, ciprofloxacin, gentamicin, imipenem, piperacillin, tetracycline, ticarcillin, ticarcillin-clavulanate, tobramycin, and trimethoprimsulfamethoxazole, they were resistant to ampicillin and ampicillin-sulbactam. Furthermore, a strain of $A$. caviae was also resistant to aztreonam.

\section{Discussion}

Bacteria of motile Aeromonas group (A. sobria, A. caviae, A. hydrophila) are common inhabitants of aquatic environments and also recognized as pathogens in amphibians and fish (Shotts et al. 1972) and snails (Popoff 1984).

Motile aeromonad species are transmitted through direct contact among animals and humans and hence the risk of the infection is relatively higher (Ghenghesh et al. 1999; Jindal et al. 1993).

Reports of disease caused by Aeromonas species in livestock and companion animals, except for humans are rare. Motile aeromonad species have been implicated as the causative agents of diarrhoea, wound infections, and septicemia in humans (Trower et al. 2000); diarrhoea (Pal et al. 1989; Efuntoye 1995; Hathcock et al. 1999), abortion and reproductive problems (Fontaine et al. 1996; Das and Paranjape 1990), septic arthritis (Traub-Dargatz et al. 1994), septicaemia (Andre-Fontaine et al. 1995), mastitis (Bergman et al. 1981), polyarthritis (Love and Love 1984), seminal vesiculitis (Moro et al. 1999), acute deaths (Shane and Gifford 1985), conjunctivitis (Garcia et al. 1992) and focal hepatic necrosis (Hiruma et al. 1986) have been associated with infection by Aeromonas species in animals.

Although the isolation of motile aeromonads from different cases has been reported, there is a little information on the incidence of motile aeromonads in animals. However, the incidence of $A$. hydrophila in the healthy animal population is higher than the asymptomatic faecal carriage rate in humans (Gray 1984). The high incidence of A. hydrophila in apparently healthy animals may therefore only reflect constant exposure to water containing the organism (Gray 1984). However, Pitarangsi et al. (1982) in the indigenus Thai population found no significant difference between faecal isolation rates of $A$. hydrophila in symptomatic (9-34\%) and asymptomatic (8-27\%) individuals.

The prevalence of Aeromonas spp. in apparently healthy animals may reflect constant exposure to Aeromonas-contaminated water (Gray and Stickler 1989). Gray and Stickler (1989) examined for Aeromonas spp. from faecal samples from 520 healthy pigs and 481 healthy cows. They reported that aeromonads were found to be minor components of the faecal flora, only $8.8 \%$ of 520 samples from pigs and $4.6 \%$ of 481 samples from cows.

In a survey, Abbey and Etang (1988) found that the incidence rates were low in poultry, cattle and humans. Because of low incidence, the authors suggested that these animals may be only transient hosts.

The isolation of motile aeromonads from dog faeces has reported in a few studies (Akan et al. 1996, Ghenghesh et al. 1999) and their isolation rates were low according to those found in other animals (Gray and Stickler 1989, Jindal et al. 1993). Ghenghesh et al. (1999) studied isolation and haemolytic activity of Aeromonas species of rectal swabs from 120 domestic dogs and 15 domestic cats. They reported that aeromonads were isolated from $13(10.8 \%)$ out of $120 \mathrm{dogs}$ and from one (6.7\%) out of 15 cats. A kan et al. (1996) reported that motile aeromonads were isolated from four $(3.4 \%)$ out of 117 rectal specimens of healthy dogs. Of these, three isolates were identified as A. hydrophila and one as A. sobria. Our results were in agreement with Akan et al. (1996) but were lower than those found by Ghenghesh et al. (1999). 
Because Aeromonas spp. are zoonotic, it is important to combat the organism. Thus, it is possible to challenge with the disease if susceptibility to antibiotics is known. For this purpose, antimicrobial sensitivity tests to the strains of aeromonads were performed and it was found that A. sobria was resistant to ampicillin; sensitive to amikacin, cefotaxime, ceftriaxone, gentamicin, tobramycin, ceftriaxone, tetracycline, trimethoprimsulfamethoxazole. Although the isolated A. caviae was resistant to ampicillin and ampicillin-sulbactam, sensitive to amikacin, ticarcillin, gentamicin, tobramycin, imipenem, ciprofloxacin, ceftazidime, cefotaxime, cefoperazone, cefotetan, piperacillin, ticarcillinclavulanate, and trimethoprim-sulfamethoxazole. Similar findings have been reported by other workers (Diker et al. 1984; Megraud 1986; Das and Paranjape 1990; Jindal et al. 1993; Kienzle et al. 2000).

However, the results obtained using commercial kits and disc diffusion technique, especially the susceptibility tests to beta lactam antibiotics shoud be verified by agar dilution technique (Schadow et al. 1993; Morita et al. 1994).

In conclusion, Aeromonas species in the faeces of domestic dogs might pose a public health problem for humans who are in direct contact with contaminated animals and treatment should be adminiastered using those antibacterial agents to which the rods are sensitive.

\section{Prevalence a citlivost vůči antibiotikům u pohyblivých Aeromonas izolovaných ze psů}

Prevalence pohyblivých aeromonád byla sledována ve faeces zdravých psů, a byla stanovena jejich citlivost vůči vybraným antimikrobiálním preparátům. Rektální výtěry od 55 domácích psů byly vyšetřeny na přítomnost Aeromonas spp. Za použití alkalické peptonové vody (pH 8.4) jako obohaceného média a selektivního agaru Aeromonas s obsahem $5 \mathrm{mg} / \mathrm{l}$ ampicillinu jako media. Idenitifikace a rezistence pohyblivých kmenů Aeromonas byly provedena pomocí Gram Negative Breakpoint ID panelu. Aeromonas byla identifikována ze tři $(5.45 \%)$ psů, z nichž u jednoho byla izolována A. sobria, u dvou A. caviae. Zatímco všechny kmeny byly vnímavé vůči amikacinu, cefoperazonu, cefotaximu, cefotetanu, ceftazidimu, ceftriaxonu, cefuroximu, ciprofloxacinu, gentamicinu, imipenemu, piperacillinu, tetracyclinu, ticarcillinu, ticarcillin/clavulanatu, tobramycinu a trimethoprim/sulfamethoxazolu, byly rezistentní vůči ampicillinu a ampicillin/sulbactamu. Navíc byl kmen A. caviae rezistentní vůči aztreonamu.

Výsledkem této studie je informace o prevalenci aeromonád u zdravých psů, o citlivosti izolovaných kmenů vůči antibiotikům, o významu těchto poznatků pro veřejné zdraví.

\section{References}

ABBEY, SD, ETANG, BB 1988: Incidence and biotyping of Aeromonas species from the environment. Microbios 56: $149-155$

AKAN, M, YILDIRIM, M, OCAL, N, DIKER, KS 1996: The prevalence of motile Aeromonas in dogs. Yuzuncu Yil University Health Sci J 2: 44-46

ANDRE-FONTAINE, G, MONFORT, P, BUGGIN-DAUBIE, M, FILLONEAU, C, GANIERE, JP 1995: Fatal disease mimicking leptospirosis in a dog, caused by Aeromonas hydrophila. Comp Immunol., Microbiol and Infect Dis 18: 69-72

BERGMAN, A, SEFFNER, W, BUSCH, S 1981: Zur beteiligung von Aeromonas hydrophila an einem Mastitisgeschehen. Mh VetMed 36: 548-553

DAS, AM, PARANJAPE, VL 1990: Aeromonas sobria in bubaline (water buffalo) abortion: Growth requirement, biochemical characters, antibiotic susceptibility, experimental pathogenicity and serology. Ind J Exper Biol 28: 341-345

DIKER, KS, AKAY, Ö, BURGU, A 1984: Characterization of Aeromonas sobria isolated from diseased Carps (Cyprinus carpio). Ankara Univ J Vet Fac 31: 508-516

EFUNTOYE, MO 1995: Diarrhoea disease in livestock associated with Aeromonas hydrophila biotype 1. J. Gen Appl Microbiol 41: 517-521 
FONTAINE, M, COLLOBERT-LAUGIER, C, TARIEL, G 1996: Abortion and fetal death of infectious origin in the mare. Summa 13: 57-62

GARCIA, ME, DOMENECH, A, DOMINGUEZ, L, RAMIRO, F, FERNANDEZ-GARAYZABAL, JF 1992 : Aeromonas hydrophila conjunctivitis in a pet parrot (Amazona versicolor). Avian Dis. 36: 1110-1111

GHENGHESH, KS, ABEID, SS, JABER, MM, BEN-TAHER, SA 1999: Isolation and haemolytic activity of Aeromonas species from domestic dogs and cats. Comp Immunol Microbiol Infec Dis 22: 175-179

GRAY, SJ 1984: Aeromonas hydrophila in livestock: incidence, biochemical characteristics and antibiotic suscebtibility. J Hyg 92: 365-375

GRAY, SJ, STICKLER, DJ 1989: Some observations on the faecal carriage of mesophilic Aeromonas species in cows and pigs. Epidemiol and Infect 3: 523-537

HATHCOCK, TL, SCHUMACHER, J, WRIGHT, JC, STRINGFELLOW, J 1999: The prevalence of Aeromonas species in feces of horses with diarrhea. J Vet Int Med 13: 357-360

HIRUMA, M, IKE, K, KUME, T 1986:ì Focal hepatic necrosis in young ferrets infected with Aeromonas species. Jap J Vet Sci 48: 159-162

JINDAL, N, GARG, SR, KUMAR, A 1993: Comparison of Aeromonas spp. isolated from human, livestock and poultry faeces, Isr J Vet Med 48: 80-83

KIENZLE, N, MULLER, M, PEGG, S 2000: Aeromonas wound infection in burns. Burns 26: 478-482

LOVE, RJ, LOVE, DN 1984: Aeromonas hydrophila isolated from polyarthritis in a calf. Aust Vet J 61: 65

MÉGRAUD, F 1986: Incidence and virulence of Aeromonas species in feces of children with diarrhea. Eur J Clin Microbiol 5: 311-316

MORITA, K, WATANABE, N, KURATA, S, KANAMORI, M 1994: Beta-lactam resistance of motile Aeromonas isolates from clinical and environmental sources. Antimicrob Agents Chemother 38: 353-355

MORO, EMP, WEISS, RDN, FRIEDRICH, RSC, VARGAS, AC-DE, WEISS, LHN, NUNES, MP, DEVARGAS, AC 1999: Aeromonas hydrophila isolated from cases bovine seminal vesiculitis in South Brazil. J Vet Diagn Invest 11: 189-191

MOYER, NP 1987: Clinical significans of Aeomonas species isolated from patient with diarrhea. J Clin Microbiol 25: 2044-2048

PAL, M, BRAHMBHATT, MN, SAVALIA, CV 1989: Association of Aeromonas hydrophila with gastroenteritis of a zoo deer. In: Erkrankungen der Zootiere. Verhandlungsberitcht des 31. Internationalen symposiums uber die Erkrankungen der Zoo-und Wildtiere, Dortmund 1989. Akademie-Verlag, Berlin. pp. 321-324

PITARANGSI, C, ECHEVERRIA, P, WHITMIRE, R, TIRAPAT, C, FORMAL, S, DAMMIN, GJ, TINGTALAPONG, M 1982: Enteropathogenicity of Aeromonas hydrophila and Plesimonas shigelloides:prevalence among individuals with and without diarrhoea in Thiland. Infection and Immunity. 35: 666-673

POPOFF, M 1984: Genus III. Aeromonas. Kluyver and van Niel 1936, 389. In: Krieg NR, Holt JG, ed. Bergey's Manuel of Systematic Bacteriology, 9th ed, Vol. 1. Baltimore, MD: The Williams and Wilkins Co, pp. 545-548

QUINN, PJ, CARTER, ME, MARKEY, BK, CARTER, GR 1994: Clinical Veterinary Microbiology. Wolfe Publishing, London, pp. 243-247

SCHADOW, KH, GIGER, DK, SANDERS, CC 1993: Failure of the Vitek AutoMicrobic system to detect betalactam resistance in Aeromonas species. Am J Clin Pathol 100: 308-310

SHANE, SM, GIFFORD, DH 1985: Prevalence and pathogenity of Aeromonas hydrophila. Avian Diseases 29: 681-689

SHOTTS, EB, GAINS, JL, MARTIN, C, PRESTWOOD, AK 1972: Aeromonas induced deaths among fish and reptiles in a eutophic inland lake. J Amer Vet Med Assoc 161: 603-607

TRAUB-DARGATZ, JL, SCHLIPH, JW, ATWELL, E, BENNETT, DG, JONES RL, EHRHART, EJ, SCHULTHEISS, PC 1994: Aeromonas hydrophila septic arthritis in a neonatal foal. Equine Practice 16: 15-17

TROWER, CJ, ABO, S, MAJEED, KN, ITZSTEIN, M 2000: Production of an enterotoxin by a gastroenteritis associated Aeromonas strain. J Med Microbiol 49: 121-126 